\title{
Vendégtanár voltam Szlovákiában
}

\section{Kovács Judit}

Eötvös Loránd Tudományegyetem Tanító- és Óvóképző Kar, Budapest

\begin{abstract}
A szerző 2013-2015 között a besztercebányai (Banská Bystrica) Bél Mátyás Egyetem Pedagógiai Karának munkájában vendégtanárként vett részt, egy Európai Uniós projekt keretében. A projekt célja az volt, hogy megismertesse a szlovák egyetemi hallgatókkal, valamint a már pályán lévő pedagógusokkal a korai nyelvpedagógia és a korai kéttannyelvü oktatás módszereit, a legújabb kutatások eredményeit. Az írásban a szerző bemutatja az olvasóknak a vendégtanitás problémáit és örömeit, a kihívás állandó megújulást igénylö érzését.
\end{abstract}

Kulcsszavak: Európai Uniós Projekt, korai nyelvpedagógia, korai kéttannyelvü oktatás, általános iskolai angolnyelv-oktatás, tanártovábbképzés.

\section{Hogyan kezdődött?}

2010 novemberében egy, a korai kéttannyelvű oktatással foglalkozó konferencián vettem részt. 'Plenary speaker' voltam, azaz a közönség egészének mutattam be prezentációmat. A színhely Pozsony volt, és a résztvevők nagy része is Szlovákiából érkezett. Előadásom után odalépett hozzám egy kolléganő, a besztercebányai (Banská Bystrica) Bél Mátyás Egyetem docense, és azt mondta, hogy náluk az egyetemen, de országos szinten is hiány van olyan szakemberekben, akiknek a korai nyelvfejlesztés és a korai kéttannyelvű oktatás a szakterületük. Ezért nagyon megörült az előadásomnak, és megkérdezte, hogy tanítanék-e az egyetemükön. Erre azért is van mód, mondta, mert az egyetemük megpályázott egy Európai Uniós projektet, amelynek keretében külföldi szakértőként segíthetném munkájukat. A pályázat 2012-ben nyert és ezzel megnyílt az út a közös munka felé.

Munkakapcsolatom Szlovákiával már több évre tekint vissza. 2009-ben a nyitrai Konstantin Filozófus Egyetemen is tartottam prezentációt, aminek folytatásaként 2010ben meghívást kaptam a pozsonyi Comenius Egyetemre több előadás és workshop tartására. 2011-ben és 2012-ben pedig már az ERASMUS oktatói mobilitás keretében voltam vendégtanár a besztercebányai Bél Mátyás Egyetemen (Univerzita Mateja Bela, UMB). A kedvező tapasztalatok hozzájárultak ahhoz, hogy meghívást kapjak a projektbe.

\section{Munka a projektben}

Munkám a Mobilities - UMB Activity 1.4 nevű European Mobility Projectben, melyet a European Social Fund finanszírozott, eredetileg négy területre terjedt ki: kurzusok tartása az UMB Pedagógiai Tanszékének hallgatói számára a korai nyelvoktatás és kéttannyelvű oktatás témájában, az egyetemen folyó kutatás támogatása, konferenciákon és workshopokon a tudományterület megismertetése, valamint az eredmények publikálása. A közös munka folyamán tevékenységem még két területtel bővült: általános iskolás tanulók oktatása, valamint tanártovábbképzés, először csak Banská Bystricában, majd más szlovákiai városokban is. A munkakapcsolat során az a megtiszteltetés is ért, hogy az Angoltanárok Szlovákiai Egyesületének elnöke is meghívott 
Pozsonyba egy beszélgetésre, majd ezt követően, egy nemzetközi konferenciára, előadónak (Pozsony, 2014. június). Ugyancsak nem várt fejlemény, hogy $A$ gyermek és az idegen nyelv címü könyvemet (Eötvös József Könyvkiadó, Budapest, 2009, 2014) olyan hasznosnak tartották, hogy most fordítják szlovák nyelvre. Megjelenése a 2016os évre várható.

A projekt időtartama alatt négy, egyenként egyhetes tanítási blokk megtartása volt a feladatom, majd ezt követően egy, a szlovák-magyar együttműködés eredményeit bemutató konferencia megrendezése a szakma legjobb magyar képviselőivel, valamint ugyanitt plenáris előadás tartása. Volt egy ötödik tanítási blokk is, melynek helyszíne Magyarország volt, ahová az UMB két vezető oktatója látogatott el, a korai angol mint idegen nyelv, valamint a korai kéttannyelvű oktatás oktatásának a tanulmányozása céljából. $E$ látogatás megtervezése és megszervezése is az én feladatom volt. Szlovák részről Dana Hanesova PhD docensasszony volt a projekt koordinátora, akivel kezdettől fogva nagyszerü szakmai és személyes kapcsolatot sikerült kialakítanom. Az ő áldozatkész, fáradhatatlan munkája, a szakma iránti elkötelezettsége, valamint a pedagógiai és emberi értékekről való közös gondolkodás nagymértékben hozzájárult ahhoz, hogy sikeres volt az együttmüködésünk.

Kurzusaimnak az egyetemen kettős célja volt: az elméleti alapok átadása mellett minden órának gyakorlati aspektusa is volt. Az órán éppen megtanult módszerek, eljárások, technikák máris megjelentek feladatok formájában, melyeket a pedagógushallgatók a tíz éven aluli nyelvtanulók tanításában akár a következő napon felhasználhattak iskolai gyakorlatukban. A projekt folyamán összesen 23 MA szintü hallgatóm volt, mindnyájan sikeresen végezték el a kurzust, melyről bizonyítványt is kaptak. A kurzus mind a hallgatók, mind az én részemről azért is jelentett kihívást, mert a hallgatók nem angol szakos, hanem általános iskolai tanítónak készültek. Nyelvtudásuk nem hasonlítható össze az ELTE TÓK-on tanuló hallgatóiméval, akik speciális angol nyelvi program szerint arra készülnek, hogy tíz éven aluli gyerekeket angolra (is) tanítsanak. Éppen azért volt szükség az én munkámra, hogy a szlovák kollégákkal együtt közösen megteremtsük az ELTE TÓK-on (és más hazai intézményekben folyó) képzéshez hasonló képzés alapjait. A kurzus zárásához feladatként mindenkitől egy Fejlődési Napló (Development Report) megírását kértem, amelyben reflektálniuk kellett arra, hogy miként gondolkodtak a szakterületről a kurzus kezdetén és hová jutottak el a kurzus végén. Az eredmény mindjárt az első csoport esetében megható volt: a 12 hallgató közösen készített el egy esztétikusan megszerkesztett kis füzetkét, a szlovák nemzeti színekkel díszített három szívvel, és olyan tartalommal, amely azt tükrözte, hogy a kurzus során nagyon hamar legyőzték fenntartásaikat és félelmeiket a külföldi, angol nyelvű oktatóval szemben, és a közvetlen, jó hangulatú órák során sikerült megszeretniük a szakmát is.

\section{Élmények, amelyeket egy oktató a pályája során kaphat....}

Pedagógusként és a tanárképzésben részt vevő szakemberként már tekintélyes múlt van a hátam mögött, mégis úgy éreztem a projekt során, hogy a tanárképzésben és továbbképzésben való részvétel tartogathat még új örömöket számomra is. Ezekböl szeretnék most megosztani néhányat a tanulmány olvasóival. Az egyik legnagyobb élményt az eredményesség jelentette: a gyerekeknek tartott óráim során sikerült megértetnem a szlovák kollégákkal, hogy az egynyelvű (célnyelvű) óravezetés jól működik. A hagyományos, csupán nyelvi készségekre alapozó nyelvoktatás szerint csak akkor érzi biztonságban magát a tanuló, ha az óra az elejétől a végéig minden szó 
az anyanyelven és a célnyelven is elhangzik. Ez a megközelítés teljesen szembenáll mindazzal, amit ma a korai fejlesztésről, és ezen belül a korai kéttannyelvű fejlesztésről tudunk. Ennek lényege az, hogy nem nyelvi, hanem kognitív fogódzót nyújt az ismeretlen lexikai vagy nyelvtani elemek megfejtéséhez a kontextus, a vizuális és egyéb szemléltetés eszközeivel együtt. Többször előfordult a kisiskolásoknak tartott óráimon, hogy a szlovák pedagógusok egy-egy nehezebbnek vélt szó elhangzásakor gyorsan a tanulók segítségére siettek a szó szlovák megfelelőjének fülbe súgásával. Meglepetésükre, erre nem volt szükség, mert a feladat- és témaalapú megközelítés ezt feleslegessé tette. Emlékszem egy példára: alsó tagozatosoknak tartottam angol mint idegen nyelv órát. A közlekedési eszközök volt a téma, melyhez a szókincset teljes mértékben gyermekdalok és mondókák adták. Amikor a 'Row, row, row your boat, gently down the stream' kezdetü, az angolszász környezetben közismert dalocskát tanítottam, a 'stream', azaz 'kis folyó' szó értelmezésére az alábbi ötletem támadt: kinéztem az ablakon, és azt mondtam: 'Látjátok, itt folyik a Garam (szlovákul Hron, ezt szerencsére tudtam), ami egy kis folyó, vagyis: stream. Mindenki megértette, föleg azután, hogy a dalocska első két sorát el is játszottuk (imitáltuk, hogy csónakban evezünk). A téma, a szövegösszefüggés, a dalt kísérő mozgás, valamint a vizuális segítség (a közlekedési eszközök képei a táblán) világossá tették a jelentést.

Hasonló sikerélményben volt részem, amikor az egyetem oktatóinak tartottam workshopot a kéttannyelvű oktatásról. Az ezt az oktatási formát nem ismerő, különböző tanszékekről jött kollégák nem is rejtették véka alá fenntartásaikat, sőt, előitéleteiket. A workshop megkezdése előtti informális beszélgetés során egy matematikus kolléga azt állította, hogy a matematika még önmagában is elég nehéz, hát még ha idegen nyelven tanítják. A testnevelők szerint pedig időigényes, tehát nem praktikus, hogy a tanórán az utasításokat idegen nyelven adják. A másfél órás, DVD-s órarészleteket is bemutató workshop szinte csodát művelt. Nézeteikben 180 fokos fordulat állt be, amire ők maguk is csak később döbbentek rá. Aznap este a workshop néhány résztvevőjével egy informális találkozás kapcsán több kolléga odajött hozzám, és elnézésemet kérte bizalmatlanságáért. A workshopom, illetve az ott bemutatott óra- és foglalkozásrészletek új, kedvező színben tüntették fel előttük a kétannyelvű oktatást, amelyet eddig azért utasítottak el, mert nem ismerték.

A számomra új, ismeretlen környezetben, szlovák kisiskolásoknak tartott angol mint idegen nyelv, illetve angol célnyelvű órák arról győztek meg, hogy a szakterület elméleti alapjai szilárdak, és a gyakorlatban jól müködnek. Bármilyen, a célnyelven tartott óra a tíz éven aluli korosztálynak akkor lehet sikeres, ha az általános ismeretek felidézésén, gyermekirodalmi alkotásokon, és szemléltetésen alapul. Egy, negyedikeseknek tartott, matematika témájú óra ${ }^{1}$, ahol a szorzást gyakoroltuk, például úgy kezdődőtt, hogy egy, a hónapok nevéről és az egyes hónapok napjainak a számáról szóló gyermekverset tanultuk meg és mondtuk el:

\footnotetext{
1 Nem szaktárgyam a matematika, azonban, mint egzakt tárgy, a matematikai alapfogalmak igen könnyen és sikeresen taníthatók célnyelven, és ily módon jól lehet érzékeltetni a kéttannyelvű oktatás kényegét. Mivel Szlovákiában még nem terjedt el az általános iskolai kéttannyelvű oktatás, ezért ilyen programú intézmények híján csakis hagyományos iskolákban taníthattam. Ezért nem tarthattam valódi kéttannyelvű órákat.
} 


\section{"Thirty days hath September, \\ April, June and November; \\ February has twenty eight alone \\ All the rest have thirty-one \\ Except in Leap Year, that's the time \\ When February's Days are twenty-nine"}

A gyermekvers nyelvtől független, általános információt tartalmaz, amely azonnal megteremtette az alapot az ezt követő játékra: az a tanuló nyer belépőt a szorzásos társasjátékra, aki meg tudja válaszolni az olyan kérdéseket, mint: 'Hány hónap van egy évben?', 'Hány napos a február?', 'Hány napos a február szökőévben?' stb. A célnyelv megértésében és a válaszadásban az általános ismeretek, valamint a vers segített. A jól válaszoló gyerekek aztán folytathatták a versengést a táblára elhelyezett nagy társasjátékon, ahol a húzott kártyák alapján a bábukat a szorzótáblának megfelelően kellett mozgatni. Ha például az állt a kis kártyán, hogy 6x6, akkor a megfelelő, tehát a 36-os mezőre kellett elhelyezni a bábut helyettesítő kis képet, táblamágnes segítségével.

Egy másik órán különböző színű és nagyságú síkidomokat, kört, négyzetet, téglalapot és háromszöget vittem be 7-8 éveseknek. A gyerekek a szőnyegen körben ülve ezeket a szakszavakat, valamint a színeket és mellékneveket olyan utasítások alapján gyakorolták, hogy: 'Vedd fel a kis rózsaszín háromszöget a szőnyegröl, és tedd a fejedre', vagy: 'Ülj rá a nagy barna körre', 'Vedd fel a kis piros téglalapot, és tedd a zsebedbe' stb. Egy másik osztályban a számokat tanítottam 1-10-ig, szókártyák segítségével. A számok nevén kívül (amit ma már szinte minden gyerek tud) csak azt a két szót tanítottam meg, hogy: 'odd' és 'even', azaz páratlan és páros. Rámutattam a szőnyegre kiteregetett szókártyákra, és azt mondtam: 'Most egy páros számra gondolok. Ez a szám nagyobb, mint 5, de kisebb, mint 7. Melyik ez a szám?' A gyerekek lelkesen jelentkeztek, hogy válaszolhassanak. Majd a következő lépés az volt, hogy ők lehettek a tanárok, azaz ők adták fel a feladatot társaiknak. A szemléltetéssel és mozgással kísért, önállóságot kívánó feladatok kellőképpen motiválták a gyerekeket, akik az élvezetes tevékenység közben elsajátítottak bizonyos szókincset is.

A tanártovábbképzések tartására az egyetemi és iskolai óráim miatt kaptam felkérést. Három egymást követő délutánon került erre sor egy Banská Bystrica-i iskolában, ahol 8 helyi és környékbeli iskolából jöttek össze gyakorló angolszakos tanárok. Lényegében igen sok rétegnek szóló komplex képzés folyt melyen a tanárokon kívül részt vettek a kisiskolásoktól kezdve hallgatóim az egyetemről, egyetemi oktatók, valamint iskolaigazgatók is.

A többéves együttmüködést lezáró közös konferenciára, melynek címe: 'Learning together to be a better CLIL teacher' volt, 2014 októberében került sor. Ezen az eseményen részt vettek és workshopot tartottak pedagógusok mindazon magyar intézményekből, amelyeket a szlovák kollégák 2014 tavaszán meglátogattak. Ezek az alábbiak voltak: A budapesti XIII. kerületi Pitypang Kétnyelvü Óvoda vezetői: Horváth Mónika, Erdélyi Nóra és Bosnyák Tamara, a Szabó Magda Magyar-Angol Kéttannyelvű Általános Iskolából Erdősné Bach Zsuzsa igazgató, Mihály István tanár, valamint 15 hetedik osztályos tanuló. István ugyanis élöben, a saját tanítványaival mutatott be egy angol nyelvü biológiaórát, amelynek nagy sikere volt a közönség körében. Jelen volt a Karinthy Frigyes ÁMK tanára Síró Enikő, a Lemhényi Dezső Iskola részéről Béni Zsuzsanna, valamint Noé Zsuzsanna, a Lauder Alapítványi iskolából, aki előzőleg már tíz évig dolgozott angol nyelvű óvodában. És természetesen jelen volt a két kolléga az ELTE 
TÓK részéről: Trentinné dr. Benkő Éva PhD az Idegen Nyelvi és Irodalmi Tanszék oktatója, valamint Szepesi Judit az ELTE Gyakorló iskolájának mentortanára.

A Projekt eredményei közé tartozik, hogy 2015-ben megjelent a 2014-es konferencia minden előadásának és workshopjának anyaga DVD-n 'Learning Together to be a Better CLIL Teacher' címmel. Ez az anyag az interneten is nyilvánosságot kapott, és széles olvasóközönséget vonz. Jó érzés tudni, hogy munkámmal hozzájárultam ahhoz, hogy egy másik ország is elinduljon a koraiidegennyelv-oktatásnak azon az útján, ahol Magyarország már nagy lépéseket tett meg.

\section{Melléklet}

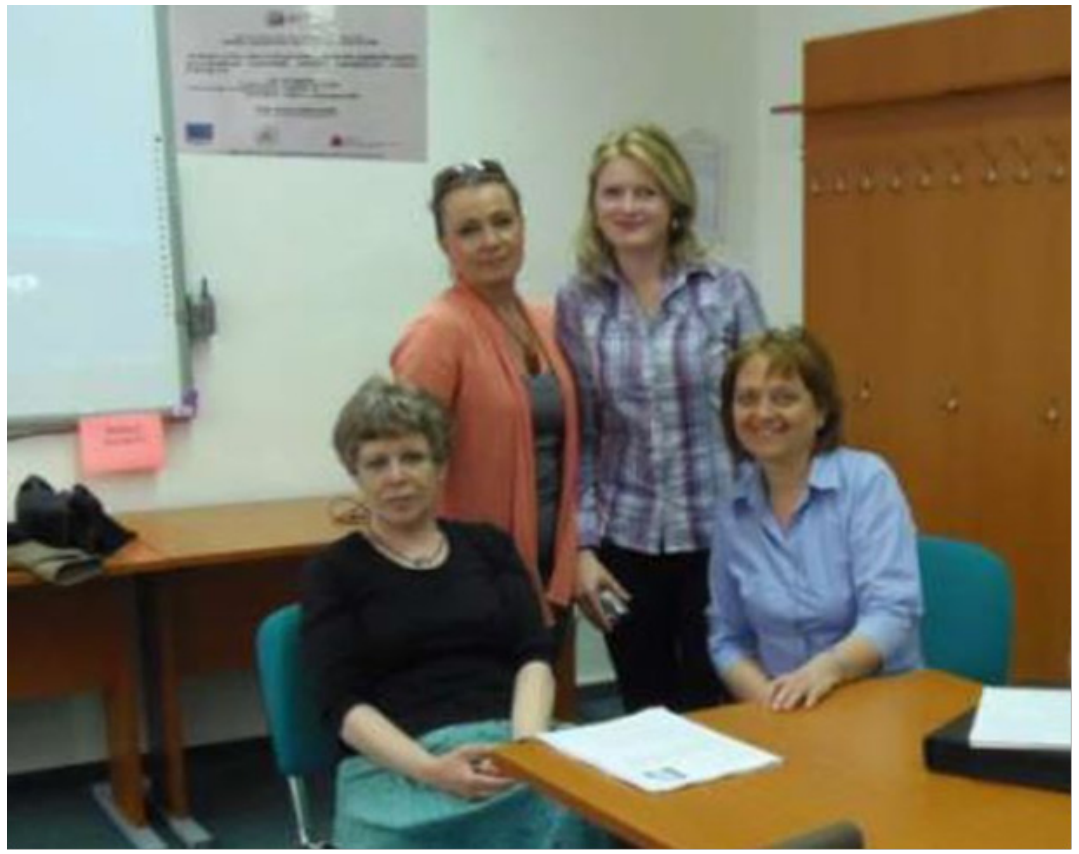

1. kép: A projekt-team. A szerző (fekete pulóverben) a projekt vezetőivel: a szerző mellett: dr. Dana Hanesová PhD, az UMB docense, a projekt koordinátora. A hátsó sorban: Dr. Bronislava Kasáčová,

$\mathrm{PhD}$, a kar dékánja, mellette: Ivana Králiková PhD, projektasszisztens

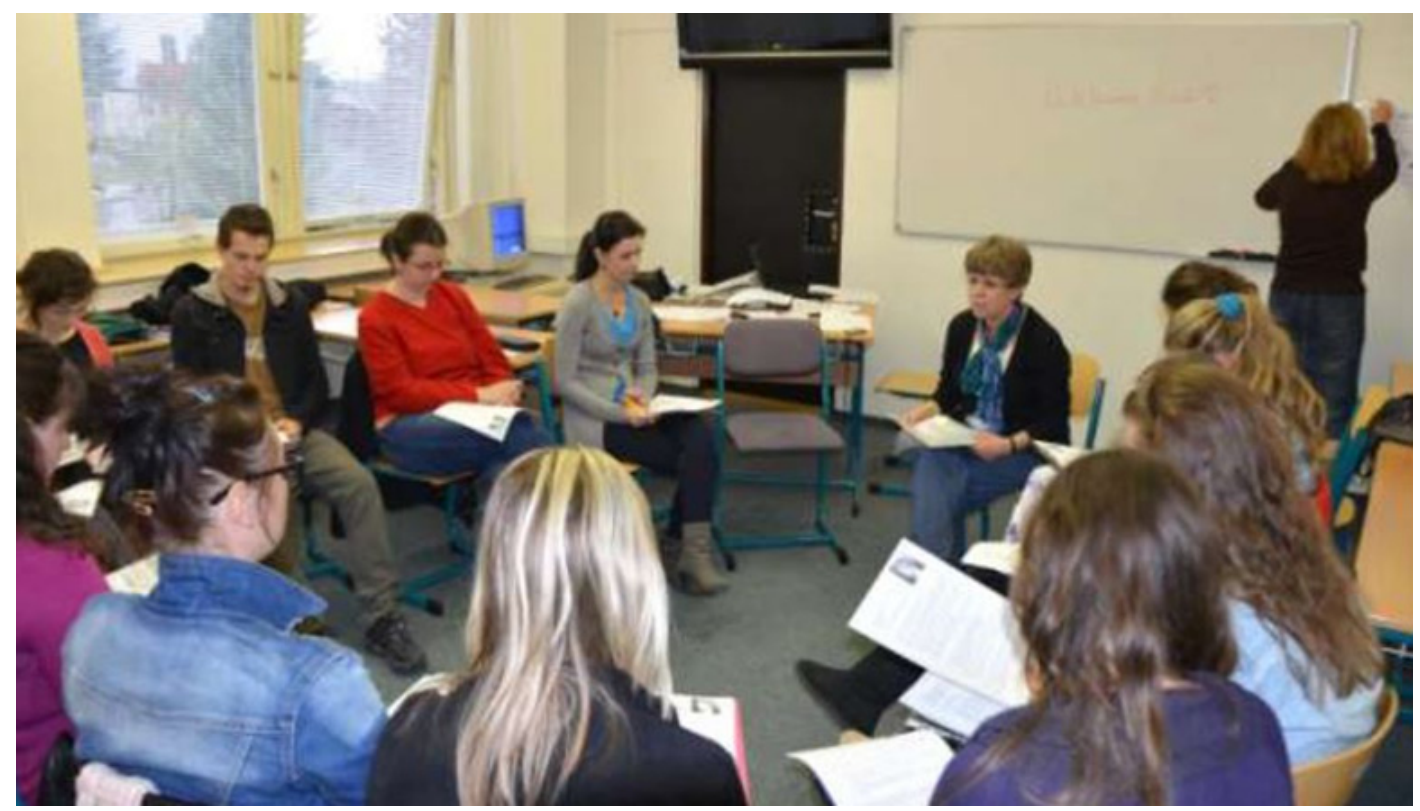

2. kép: A szerző órát tart az UMB hallgatóinak 


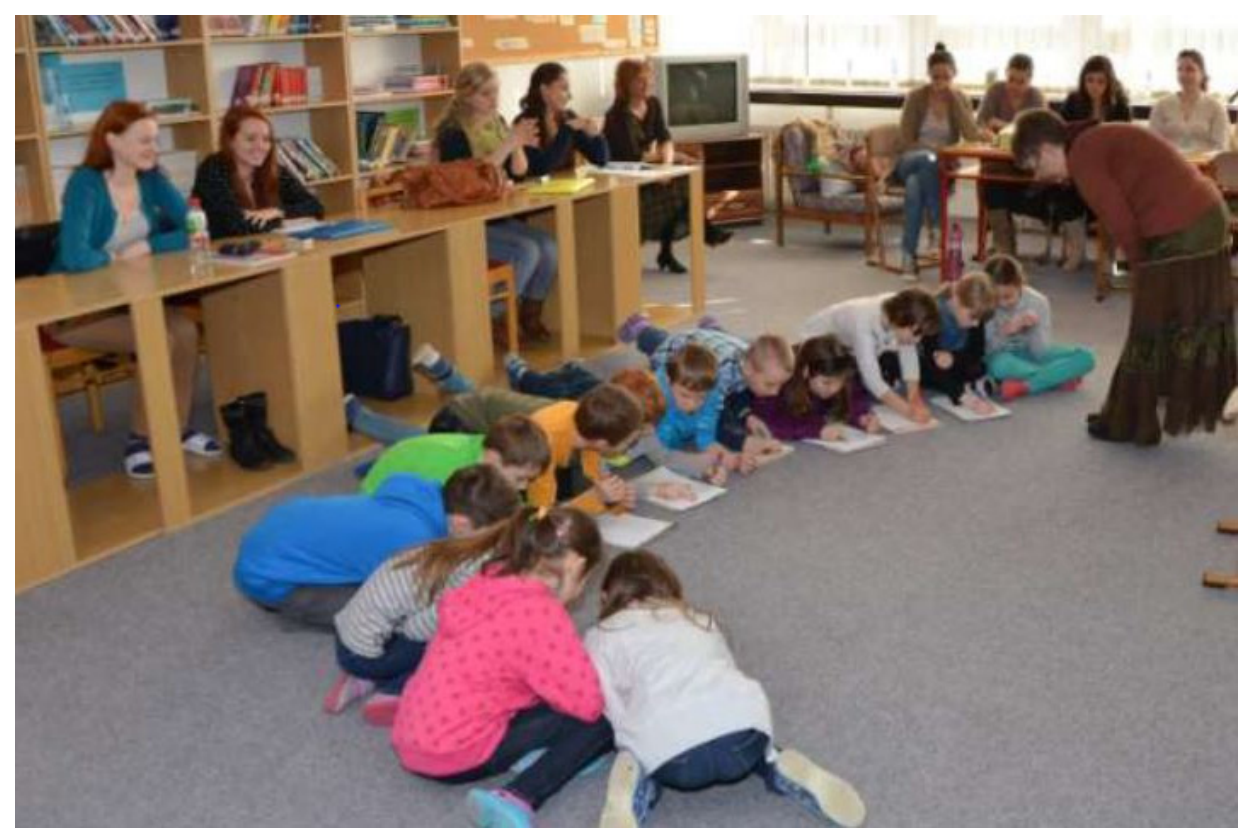

3. kép: Tanártovábbképzés egy Banská Bystrica-i általános iskolában. Előtérben a gyerekek, a háttérben az egyetemi hallgatók, illetve a tanártovábbképzés résztvevői

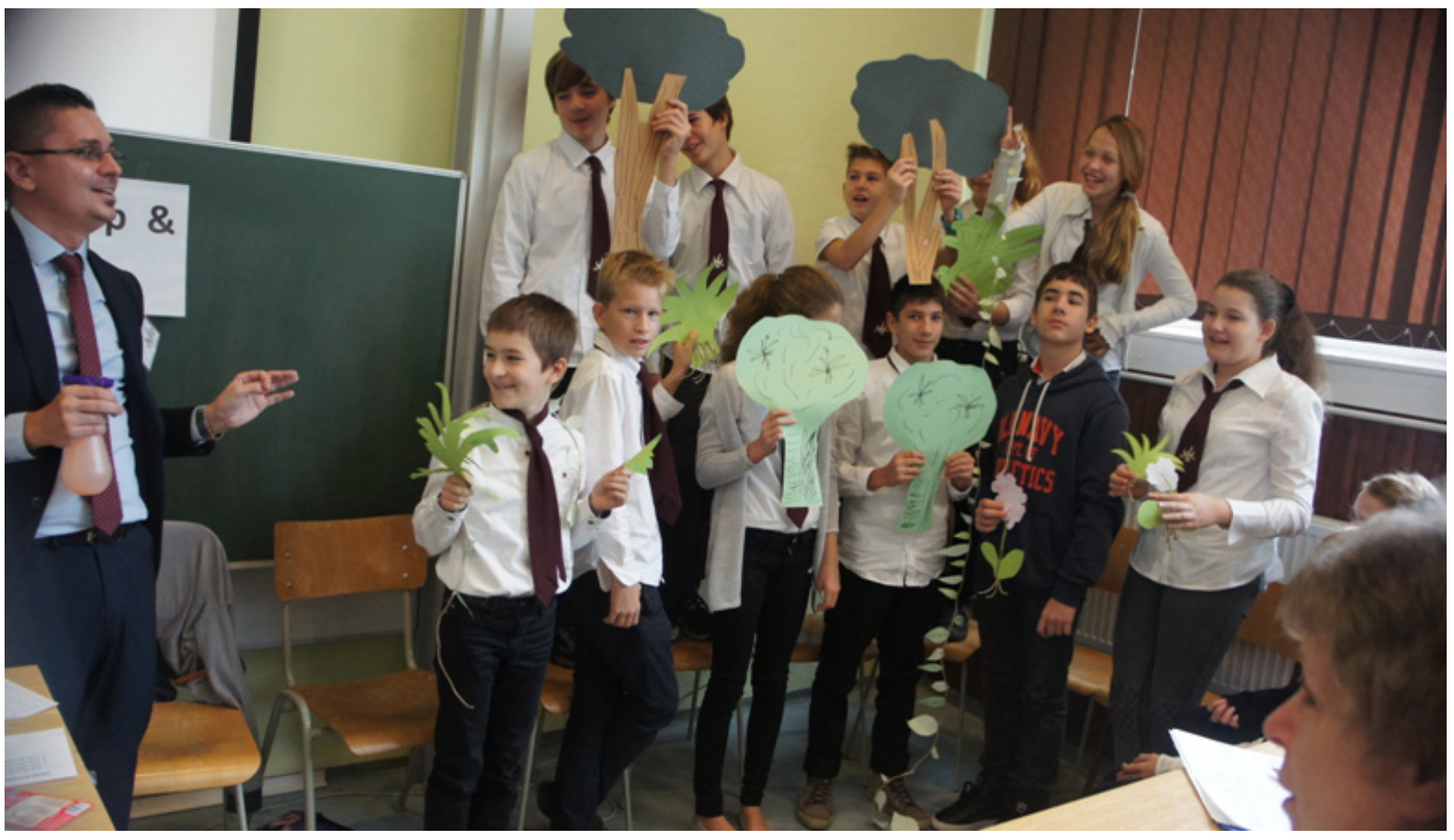

4. kép: Angol nyelvű biológiaóra Banska Bystricában, 2014. október 16-án, a projekt zárókonferenciáján. A tanár: Mihály István, a tanulók: a Szabó Magda Magyar-Angol Kéttannyelvü Általános Iskola 7. osztályos tanulói 


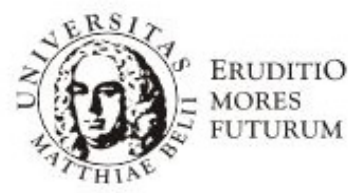

Faculty of Education

Matej Bel University, Banská Bystrica, SR

\section{LEARNING TOGETHER}

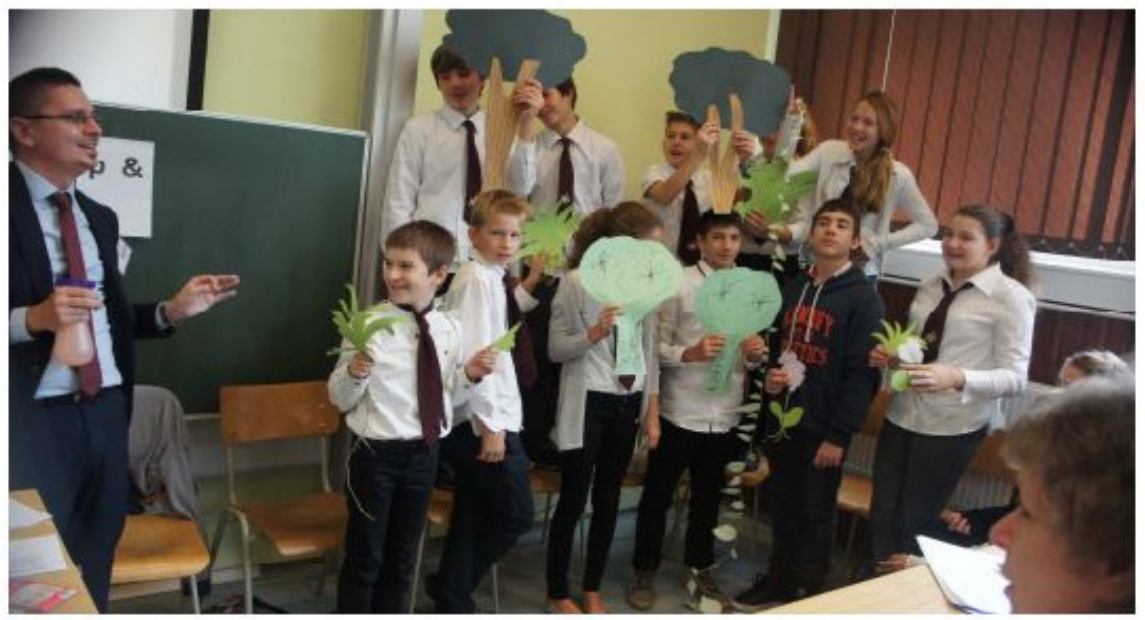

TO BE

\section{A BETTER CLIL TEACHER}

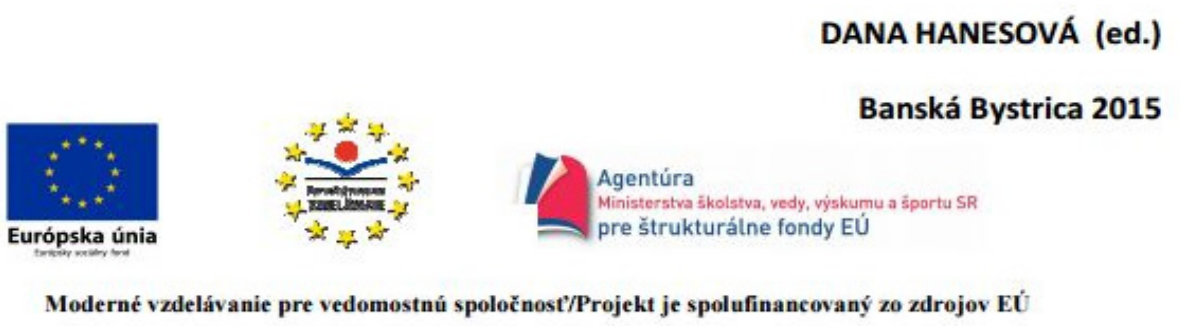

5. kép: Az interneten is elérhető konferenciakiadvány borítója 
During this seminar I really looked forward. I have learnt a lot. At the beginning I thought we will learn a lot of methodology so 1 was afraid. But it was different. I like that our teacher connected theory with practice. I have learn some new games, for example. taboo game, domino game, fruit salad... Which are focused on linguistic or now linguistic development. We saw a lot of videos from pre-school or primary school that were really important, attractive and educationals We all could see how different teachery are working with children. 1 got some new skills and improved my vocabulary. I have learnt a lot of new information and facts that 1 believe are going to be really helpful for me in the future.

1 am really thankful for the chance to complete this seminar. I know my English really isn't great. But this seminar gives me a motivation to improve my knowledge.

\section{6. kép: Lap a hallgatók által írt Fejlődési Naplóból}

In the beginning of course 1 was quite shy and inhibited, because 1 didn't use my English for a long time. But very soon - on the second day - I felt more safe and I didn't worry making mistakes. Not only my

English was developed, I also got a lot of us information about and it is what 1 expected. I' $\mathrm{m}$ sure activities with my children in the future me however I'm 21 years old (-). In my future profession 1 would try to apply all important things I learned, mainly activity - based learning, TPR, LA (what doesn't mean Los Angeles(-)) Low affective filter, etc. I' $m$ very happy that I could experience that teaching English can be fun and interesting, not only videos but also for our lessons.

Slárka Nožinová

7. kép: Lap a hallgatók által írt Fejlődési Naplóból 